\title{
Values, Spirituality and Religion: Family Business and the Roots of Sustainable Ethical Behavior Running head: Values, Spirituality and Religion in Family Business
}

\author{
Joseph H. Astrachan
}

Witten Institute for Family Business

Witten/Herdecke University, Witten (Germany)

$\&$

Smith Family Business Initiative at Cornell University (US)

E-mail: jastrach@gmail.com

\section{Claudia Binz Astrachan*}

Lucerne University of Applied Sciences and Arts, Lucerne (Switzerland)

$\&$

Witten Institute for Family Business

Witten/Herdecke University, Witten (Germany)

E-mail: claudia.astrachan@ @slu.ch

\author{
Giovanna Campopiano \\ Centre for Family Business \\ Lancaster University Management School, Lancaster (UK) \\ Bailrigg, LA1 4YX \\ Phone: +44 (0)1524 592492 \\ E-mail: g.campopiano@lancaster.ac.uk \\ Massimo Baù \\ CeFEO - Centre for Family Enterprise and Ownership \\ Jönköping International Business School, Jönköping (Sweden) \\ E-mail: massimo.bau@ju.se
}

\section{i. Compliance with Ethical Standards}

The study does not involve human participants and/or animals.

\section{ii. Conflict of Interest}

No potential conflicts. No external funding was received.

\section{*Corresponding Author}




\section{Values, Spirituality and Religion: Family Business and the Roots of Sustainable Ethical Behavior}

\section{Abstract}

The inclusion of morally binding values such as religious - or in a broader sense, spiritual values fundamentally alter organizational decision-making and ethical behavior. Family firms, being a particularly value-driven type of organization, provide ample room for religious beliefs to affect family, business, and individual decisions. The influence that the owning family is able to exert on value formation and preservation in the family business makes religious family firms an incubator for value-driven and faith-led decision-making and behavior. They represent a particularly rich and relevant context to re-assess the relationship between ethical beliefs, decision-making processes and behaviors in business organizations at the interface between family and professional logics. This Special Issue is dedicated to deepening our understanding of the role religious values and spirituality play in the formation of organizational ethical practices in faith-led family firms and resulting organizational and family-related outcomes. In this editorial, we introduce the 10 papers included in this Special Issue, which investigate the relationship between religion or spirituality and family firm ethical behavior in various geographical, cultural and religious contexts, using a multitude of qualitative and quantitative methodologies. By focusing on the effects of religious or spiritual orientations on both the business and the family, as well as on the values, norms and goals present in the family business system, further research can gain a more nuanced understanding of the relationship between religious and spiritual believes, and sustainable ethical behavior in family firms.

Keywords: Family Business, Religion, Spirituality, Faith-Led Organizations, Ethical Behavior, Values, Goals 


\section{Values, Spirituality and Religion: Family Business and the Roots of}

\section{Sustainable Ethical Behavior}

"Because of the controversial nature of religious topics, many leaders simply shy away from the talk of spirituality altogether. However, such a reaction can be an unfortunate neglect of a powerful and important tool for leadership."

(LCDR Justin Top, Marine Corps Gazette, August 2019, p. 66)

\section{Religious and spiritual ethicality in family business}

Ethical behavior in business, in its most basic form, alludes to the adherence to honesty, transparency and fairness in one's interactions with stakeholders (e.g., Crossan et al., 2013). And while we want to believe that others share our own perceptions of what is honest and fair behavior, and thus, our understanding of ethicality, these are largely dependent on an individual's underlying principles and values (e.g., Driscoll et al., 2019; Pirson et al., 2017). Research consistently shows that values play an important role in shaping an individual's personal and professional ethos (Treviño et al., 2006) and ultimately, their decision-making and behavior in the business context (Wang \& Hackett, 2016). While ethical decision-making has been a popular research topic business ethics literature for decades (e.g., Ford \& Richardson, 1994), we have more to learn about how different types of values manifest themselves in decision-making and other organizational processes in different types of organizations (Treviño et al., 2006).

Prior research shows that family-owned companies - the most prevalent form of business organizations around the world (La Porta, Lopez-de-Silanes, and Shleifer, 1999) - differ from their non-family counterparts in terms of their desire for ethical behavior (e.g., Adams, Taschian, \& Shore, 1996; Blodgett, Dumas, \& Zanzi, 2011; Yusof, Mohd Nor, \& Edward Hoopes, 2014). And while there are notable and public examples of highly unethical family firms, the majority of research strongly suggests that family firms more typically strive for 
ethical behavior, including the protection of all stakeholders (Cruz et al., 2014; Marques et al., 2014). This may be related to the fact that while all firms operate within governmental regulation and enforcement as well as social pressure from associations and interest groups, in family firms, the family ownership group adds an additional layer of oversight. Family owners are invested in fostering longevity and preserving the family reputation, which gives them additional motivation and commitment to oversee their business, ensuring its alignment with the family values and goals, which often extend beyond financial returns (Cennamo et al., 2012).

It is thus not surprising that family firms have been found to be a particularly value-driven type of organization (Olson et al., 2003), with their core values being derived from and reinforced by both the owning family and the business system (Distelberg \& Sorenson, 2009), and sometimes - as scholars have pointed out recently - a third domain: religion or spirituality (Discua Cruz, 2013; Kellermanns, 2013; Paterson, Specht, \& Duchon, 2013; Sorenson, 2013). The inclusion of morally binding values such as religious - or in a broader sense, spiritual values fundamentally alter organizational decision-making and ethical behavior (Discua Cruz, 2013; Hilary \& Hui, 2009; Kellermanns, 2013; Paterson et al., 2013; Sorenson, 2013). The importance that many owning families attribute to their central values (Denison, Lief, \& Ward, 2004) and the influence they are able to exert on value formation and preservation in the business (Naldi et al., 2013) make religious family firms an incubator for value-driven and faith-led decision-making and behavior. They represent a particularly rich and relevant context to re-assess the relationship between ethical beliefs, decision-making processes and behaviors in business organizations at the interface between family and professional logics (Gümüsay et al., 2019; see also Fritzsche \& Oz, 2007; Hilary \& Hui, 2009; Loe, Ferrell, \& Mansfield, 2000). Family firms provide ample room for religious beliefs to affect family, business, and individual decisions (Discua Cruz, 2013; Kellermanns, 2013). Such beliefs are often rooted in the 
founder's religious convictions that are conveyed through generations, permeating the business and shaping organizational values and culture (Sorenson, 2013), and organizational and individual behavior (Paterson, Specht, \& Duchon, 2013). In some way, spirituality and religion could be seen as overarching logics that provide a set of principles guiding everyday practices and relations, including those with employees, customers, the community, suppliers, and other external constituents (Balog, Baker, \& Walker, 2014). Though often overlapping, religion and spirituality have been differentiated over time, as religion mostly relates to institutional elements such as church membership, church attendance, and commitment to the belief system of a church, while spirituality encompasses individual experience and relates to personal transcendence, supra-conscious sensitivity, and meaningfulness (Hill et al., 2000). Nonetheless, "Religion is extremely effective at developing spirituality because it provides a framework of meaning, values, and connections to a like-minded community and something greater than self"' (Top, 2019, p. 67).

Given that "ethical behavior must begin at the top" (Stead et al., 1990, p. 238), and that family firm culture is often shaped by the owning family's values, it follows that faith-driven family firms may be a particularly fruitful context to study ethical intent and behavior. This Special Issue aims to contribute to filling the empirical and conceptual void on research focusing on family business, spirituality, religion and ethics, (Vazquez, 2016), contributing to a better understanding of how owning family's religious and spiritual beliefs shape the characteristics and behavior of the family and the business system.

Towards a religion-based understanding of ethical behavior in family business: articles in

\section{this special issue}

We were fortunate to be able to include 10 papers in this Special Issue that investigate the relationship between religion or spirituality and ethical behavior in family firms in various geographical, cultural and religious contexts, using a multitude of qualitative and quantitative 
methodologies. The conceptual framework below serves as a visualization of the areas covered, as well as our understanding of the role religious values play in the formation of organizational practices in faith-led family firms and resulting organizational and family-related outcomes.

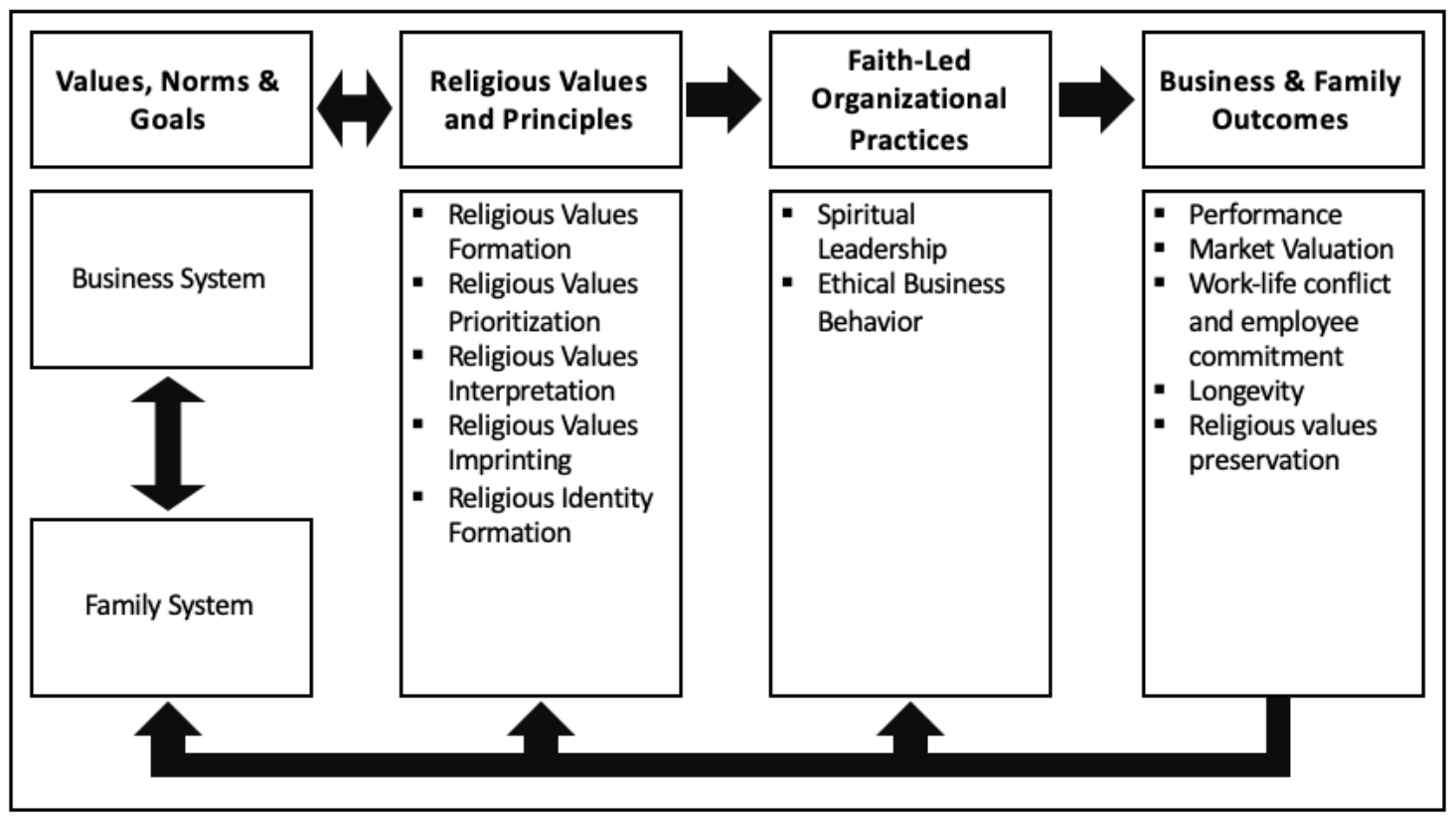

Figure 1: Conceptual Framework

Subsequently, we present the papers selected for this issue, within three categories loosely aligned with our conceptual framework. We outline the contribution of each paper, and close with a discussion of future areas of research, and a brief conclusion. Please note that the papers are not listed in the order of their appearance in the Special Issue.

\section{Value Formation, Preservation, Imprinting, and Identity Formation}

In their recent article in the Academy of Management Journal, Gümüsay, Smets and Morris (2019), using the example of the first Islamic bank in Germany, develop the concept of elastic hybridity, which pertains to a hybrid organization's ability to simultaneously engage in different logics. Their important contribution furthers our understanding of how organizations characterized by multiple logics deal with logical inconsistencies and incompatibilities. However, the authors omit the most prevalent type of organization around the world, which is 
a prime example of organizational paradoxes and contradictory logics: The family firm. Fathallah, Sidani, and Khalil's (2020) study focuses on this particular type of hybrid organization, while also applying an institutional logics perspective. The authors, using a sample of 13 Lebanese family firms, six of which are controlled by Muslim, and seven of which are controlled by Christian families, investigate how the religious logic interacts with other logics when family firms are facing ethical dilemmas. Introducing the concept of religious fluidity, the authors argue that religious values can be interpreted differently when logics conflict, which "helps manage tensions in organization" (Fathallah et al., 2020). Furthermore, their data allows them to distinguish between how different religious values and principles affect decision-making, insofar that Muslim family firms tend to apply a rule-based, while Christian family firm's favor a principle-based approach to decision-making.

Emphasizing the transgenerational values transmission in business families (e.g., Chua et al., 1999), Barbera, Shi, Agarwal, and Edwards (2020) conceptualize the family as a "perpetuator of religious values across successive generations". They authors analyze the mechanisms by which religious values are transferred between generations of the Kiolbassa family, a US-based States sausage maker. They investigate how the family's core religious values shape the ethical behavior espoused by the firm on the one hand, and the level of cohesion within the owning family on the other. Their data support their proposition that religious values and intergenerational solidarity - “when family members' interpersonal relationships exhibit strong loyalty and cohesiveness resulting in shared purposes and consensual decision-making" (Barbera et al., 2020) are iteratively reproduced over time, leading to the adoption of valuesbased leadership principles across generations. Their article makes an important contribution to the large body of research on values-based leadership, by investigating not only the consequences and advantages (e.g., Copeland, 2014), but also the origin, i.e. the process by which values-based leadership is created, developed, and maintained, and its potential 
disadvantages for family and business. This research thus contributes also to the debate around family legacy, suggesting that religion might be an important component of the social legacy that the owning family perpetuates from generation to generation (Hammond et al., 2016).

Dielemann and Koning (2020) also use time as a central dimension in their investigation of how one leader's religious and business identities have co-evolved and merged over time. Using rhetorical analysis, and adopting an identity work approach, they find that the values of one second-generation Chinese-Malaysian Christian business leader are rooted in religion, culture and sustainability, and that the way in which these values are expressed is highly contextual, relational and aspirational, rather than (as previously assumed) historical. Interestingly, they find that out of three sources of identity (religious, cultural, corporate), the Christian identity work emerged as the most influential, despite it not being part of the founder's legacy. This contributes to the extensive debate of values formation in studies that rely on history, indicating that family business leaders need not be trapped in historically embedded beliefs, but can instead adhere to values linked to various sources of family business identity.

\section{Faith-Led Organizational Practices}

Adopting a processual perspective on the decision-making process, Kavas, Jarzabkoswsi and Nigam (2020) investigate how Islamic religious values affect business activities in Turkish family firms. By means of two case study with Anatolian family businesses they find that religion acts as guiding principle through the owning family's adherence to religious values. Not only does the family import religious values as business practices, which leads them to pursue activities that are aligned with their values foundation, and to avoid those that contradict their underlying religious beliefs. Their article further shows how "religious values define and limit the nature of rationality that guides business activities" (Kavas et al., 2020). This indicates a deep entanglement between religion and business, where the former creates a comprehensive system of meanings within which business actions are formulated. This perspective offers 
contradictory evidence to the general assumption that religion and business may not coexist harmoniously (Wicks, 2014). On the contrary, this paper shows that in faith-led contexts, religion plays a constitutive role for the business by providing a widely shared meaning system.

Looking at the effects of ethical behavior in family firms, Carradus, Zozimo and Discua Cruz (2020) investigate how faith-led business practices affect the "emergence and development of stewardship in family businesses". Using a Christian-based understanding of stewardship, which is reflected by a balance of interest between an owner or manager's responsibility to God on the one hand, and to his or her fellow (wo)man on the other, their contribution furthers our understanding of stewardship orientations, which generally assumes its origins in psychological or sociological factors (e.g., Hernandez, 2012; Neubaum et al., 2017). Using an open-systems analysis of six autobiographies of Christian family businesses, the authors find that "faith-led practices not only shape the way stewardship develops, but also support the emergence of new stewards across the organization" (Carradus et al., 2020). This interestingly challenges the afore-mentioned assumption that values, principles and norms are guided from the top, instead suggesting that individuals, regardless of their hierarchical roles, can influence value formation and preservation. This mechanism may be particularly critical in family firms, where individuals contribute to organizational culture and managerial action both positively (e.g., Davis, Allen, \& Hayes, 2010; Vallejo, 2009) and negatively (e.g., De Massis, Kotlar, Mazzola, Minola, \& Sciascia, 2018; Kidwell, Kellermanns, \& Eddleston, 2012).

Lastly, Bhatnagar, Sharma, and Ramachandran (2020) investigate the role that religious beliefs play in corporate giving among large family-owned companies in India. Adopting a case study approach, the authors find that Dharma (duty towards society) and Karma (right to action), two essential spiritual beliefs in Hinduism, instill a culture of duty-bound giving in Hindus. They identify four types of family firm philanthropists - devout, committed (both of which surpass the mandated Corporate Social Responsibility expenditures), devoid and coerced (both of 
which suppress philanthropic activities) givers - that differ in their motivations and proclivity to corporate giving, indicating the presence of corporate philanthropic diversity. They find that, among other factors such as firm age and level of professionalism, the family's motivations for corporate giving largely depend on their prioritization of Dharma (adherence to religious believes) versus Karma (promotion of social equity and justice), thus advancing our knowledge of corporate giving in the understudied Indian context.

\section{Business and Family Outcomes}

Tabor, Madison, Marler, and Kellermanns (2020) adopt a conservation of resources theory lens to investigate the relationship between spiritual leadership, employee commitment and workfamily conflict in family firms. Their unique database, consisting of primary triadic data from family firm leaders, family and nonfamily employees in 77 family firms in the United States lends support to their hypothesis that spiritual leadership positively affects organizational commitment. Opposite to what they were expecting, however, they find that spiritual leadership does not lessen the effect that work-life conflict has on employees' organizational commitment, but instead exacerbates it - but only for non-family employees. This indicates different cognitive processing for these employee groups, and "that nonfamily employees may not experience the same sense of meaning and belonging in the firm" (Tabor et al., 2020). Nonfamily employees' goals may not be as closely aligned with business goals as family employees', which would then lessen the relevance of spiritual leadership for this group of employees. This study explores the much-researched relationship between organizational commitment and work-life conflict from a novel angle - spiritual leadership - while differentiating between different groups of employees, thus providing a new perspective that could further deepen our understanding of this phenomenon.

Maung, Miller, Tang, \& Xu (2020) analyze the financial market responses to a total of 1572 corporate donations by S\&P 1500 firms to test their hypothesis that "charitable donations are 
viewed more positively by investors when they are seen to be based on ethical moral considerations which sustain firm reputation, rather than attempts at self-serving ingratiation by careerist executives". Using Coarse Exact Matching (CEM) analysis to match religious with non-religious CEOs, while controlling for ownership status and firm characteristics, the authors find that find that the markets indeed react most positively to charitable donations from companies run by CEOs who openly espouse their religious believes - but only if these companies are family-owned. They argue that investors perceive these corporate donations as authentically generous, making their ethical positions more credible. Their article deepens our understanding of the possible origins and consequences of corporate giving (e.g., Campbell, Gulas, \& Gruca, 1999), and of market-based perceptions of such activity (Patten, 2008), incorporating faith-led giving as potential explanatory variable.

Goal-Setting, and the simultaneous pursuit of multiple - and possible competing - goals in family firms has attracted much attention over the last decade. Most current research differentiates between family- and non-family centered goals, as well as financial and nonfinancial goals (e.g., Binz Astrachan, Ferguson, Pieper, \& Astrachan, 2017; Kotlar \& De Massis, 2013). Drawing from the literature on goal setting and temporal orientation, Pieper, Williams, Manley, and Matthews (2020) theorize and empirically test how family firm's selfassessed religiosity affects their short-term and long-term goals, and subsequently, goal impact on firm performance and family cohesion. Applying Partial Least Squares Structural Equation Modeling (PLS-SEM) to analyze their sample of 105 US-based family firms, the authors find that more prevalent religious orientations are more strongly related to long-term than short-term goals. In addition, they find that short and long-term goals are inversely related to performance and cohesion, with short-term goals driving performance and inhibiting family cohesion, and vice versa. Their contribution deepens our understanding of the relationship between family 
firm goals and business-related outcomes by highlighting the relevance of the temporal dimension and proposing religiosity as an additional driver in the goal-setting process.

Lastly, Abdelgawad and Zahra (2020) conceptually explore how business families' religious identities affect their proclivity and ability to strategically renew their companies. The authors argue that this capacity is dependent on the owners' ability to deal with conflict and manage resources, given that the different strategic choices available require them to collectively assess and select among these options. Hypothesizing that intra-familial conflict resolution and resource allocation capabilities are shaped by the family's religious identity on the one hand (which can be insular or pluralistic), and spiritual capital (which can be internal or external, and refers to one's willingness to engage with communities with similar or different interpretations of their own faith) on the other, they propose that a religious values foundation can serve as a double-edged sword in the context of strategic renewal. An insular religious identity (i.e., connecting with proponents that strictly adhere to specific religious principles), for example, can help mitigate conflict, but it can also lead to behavioural rigidities. Their work extends prior research on strategic renewal by incorporating religious or spiritual values as an influential force in the strategic renewal process (Ravasi \& Lojacono, 2005).

\section{Suggestions for future research}

\section{The business system}

While the research represented in this Special Issue mostly looks at the effects that spiritual or religious values have on business practices in general, there is more to learn about how they affect specific business activities. Interesting areas might include business strategy development and implementation, risk-taking propensity, and stakeholder relationships. Other areas such as compensation and benefits, employee evaluation and development, recruitment and retention activities, retirement and outplacement policies, product and service pricing, accounts payable and receivable policies, the use of leverage, public relations and marketing, 
community and charitable activities, product development and innovation as well as environmental, social, and governance (ESG) are also likely to be affected by the owning family's religious underpinnings.

One of the previously identified potential strategic advantages of family businesses is in the ability to maintain connection of a far-flung enterprise by locating family members in different geographies and utilizing the family's internal cohesion as a source of firm centralization and global bonding. Perhaps one of the most well-known examples of this is the Rothschild family who used this strength to establish a banking network in Frankfurt, Paris, London, Naples and Vienna. Religious organizations may provide a similar competitive advantage, assuming that senior leadership is strongly connected through their religious associations - even more so in family-owned faith-led organizations, where members are additionally connected through their family bonds. This could have profound effects on how we think about economic development and the diffusion of business models, technology and the like.

Family business and religion might have a profound impact on supply chain networks. It is not uncommon to find family members scattered throughout a supply chain which in some ways constitutes an unofficially vertically integrated enterprise. The advantages of such a constellation of businesses include reduced transaction costs as shared values and long-term commitments guard against exploitative behavior (Lewer, \& Van den Berg, 2007). It would be interesting to explore the similar effects, if any, in religious networks and investigate comparisons with family companies in such networks, non-family companies in such networks, and family and non-family companies which are not connected through a religious or spiritual network.

\section{The family system}

There is a growing interest in the family as the main unit of analysis in the family business field and here, too, one can find fertile ground for future research. For example, how do the family's 
religious and spiritual orientation and beliefs affect how children are raised and how future owners are developed, how the family contends with intra-family conflict, or how goals are developed and infused in the organization? Barbera et al. (2020) and Dielemann et al. (2020) allude to the mechanism of values imprinting on the business identity as well as next generation members in faith-led family organizations, which may be a good starting point for further research in this area.

As exemplified by Gümüsay et al.'s (2019) recent contribution, there is a growing interest in how hybrid organizations operate under multiple and possible competing logics - particularly when facing a decision that may cause an ethical dilemma (see also García-Álvarez \& LópezSintas, 2001; Stead, Worrell, \& Stead, 1990). Multiple logics are - due to the inextricable relationship between the family and the business - at the very core of family-owned firms, requiring stakeholders to continuously make decisions and engage with practices that are consistent with these logics (e.g., Combs, Shanine, Burrows, Allen, \& Pounds, 2019; Soleimanof, Rutherford, \& Webb, 2018). Faith-led family firms, because of the morally binding nature of religious or spiritual values, may be a particularly rich environment to investigate the coexistence of several logics (i.e., family, business, religion), which may at times be paradoxical, superordinate, or complementary, and to further explore the characteristics of fluid logics such as religion in the decision-making process (Fathallah et al., 2020). As exemplified by Gümüsay et al.'s (2019) recent contribution, there is a growing interest in how hybrid organizations operate under multiple and possible competing logics - particularly when facing a decision that may cause an ethical dilemma. Faith-led family firms may be a particularly rich environment to investigate the coexistence of several logics (i.e., family, business, religion), which may at times be paradoxical, superordinate, or complementary, and to further explore the characteristics of fluid logics in the decision-making process (Fathallah et al., 2020). 
Further interesting research areas pertaining to the relationship between ethics, spirituality and family system include the effects that religious or spiritual beliefs have on (1) family identity, identification and commitment, on (2) family cohesion, emotions, intra-familial communication and conflict management, (3) the morale of the family members (particularly in times of crises) and (4) family governance.

\section{Values, Norms and Goals}

Goal-setting has a tremendous impact on achieving a dynamic state of balance among multiple institutional logics is. The goal literature in family business advances the distinction between family-centered and nonfamily-centered goals as well as the distinction between financial and non-financial goals (e.g., Chrisman, Chua, Pearson, \& Barnett, 2012), and highlights the mechanisms in setting them (e.g., Kotlar \& De Massis, 2013). However, little is known about the linkage between religious beliefs and goals in family business, even though this has been suggested as an important link better understanding the non-financial component of family firm goals (Kellermanns, 2013). Firm religiosity might indeed help family businesses pursue nonfinancial goals by engaging with external stakeholders and thus contributing to firm performance (Fang, Van de Graaff Randolph, Chrisman, \& Barnett, 2013).

Lastly, there are numerous business associations related to the pursuit of religious values in the goals, strategies and management of business organizations. Such associations include the Christian Business Council, Jewish Business Network, Islamic Business Association, Confucian Merchants Conference, Sikh Entrepreneur Network, Buddhist Business Network, and the World Hindu Economic Forum. These associations can not only provide excellent access to their membership base for research purposes; they themselves can also serve as research subjects. One potential avenue for future research would be to examine their effects on family business management by exploring their activities and impact on individual business owning families as 
well as through their impact on the communities of interest that such families create as an extension of these associations.

In the context of values, norms and goals, future research could explore the effects of religious or spiritual values on (1) financial and non-financial, family and business centered goals, and on (2) prosocial, ethical goals, citizenship and community social responsibility and philanthropic activities. Furthermore, it could investigate if (and if so, how) religious or spiritual beliefs serve as a unifying, or overarching logic in the family business system.

\section{Conclusion}

The debate about the role of religion and spirituality in generating and shaping family and business values, practices, and outcomes has only scratched the surface of a phenomenon that has great potential in furthering our understanding of family businesses and business families in particular, but also value-driven organizations in general.

Addressing the roots of ethical behavior, the articles in this Special Issue offer insights towards a more nuanced and clearer view of business issues at the interface of family business and ethics (Vazquez, 2016). Our framework presents a simple lens that allows us to think about where values in family firms originate, how they generate and reinforce identity in the family and the business, and how these values-based underpinnings, in turn, affect practices in the family and the business, and therefore, family-related and organizational outcomes. This conceptualization of the values-based family business can enrich our understanding and substantiate - or threaten - our core assumptions about family business behavior, thus representing a starting point to advance theories in the family business field.

An ethics-based and faith-based view may serve us in identifying the reference point used by families in making decisions; it can contribute to the discussion about agency-oriented and stewardship-oriented behavior (e.g. Madison et al., 2016), and it can inform the debate about 
the role of relationships along the life cycle of the family and the business (e.g., Daspit et al., 2016). Further, the recent applications of family theories to the business realm (e.g., Combs et al., 2019) should not overlook the importance of religious and spiritual values as important foundation of business families' decisions and behaviors.

Family business and business families offer a wide range of opportunities to further investigate and significantly contribute to our understanding of the relationships between religion, spirituality and ethics in businesses. We hope that the articles in this Special Issue will stipulate interest beyond the family business research community and inspire further research on the subject that benefits businesses, academia, and society in general.

\section{References}

Abdelgawad, S., Shaker, Z. (2020). Family Firms' Religious Identity and Strategic Renewal. Journal of Business Ethics.

Adams, J. S., Taschian, A., \& Shore, T. H. (1996). Ethics in family and non-family owned firms: An exploratory study. Family Business Review, 9(2), 157-170.

Balog, A. M., Baker, L. T., \& Walker, A. G. (2014). Religiosity and spirituality in entrepreneurship: a review and research agenda. Journal of Management, Spirituality \& Religion, 11(2), 159-186.

Barbera, F., Shi, H.X., Agarwal, A., \& Edwards, M. (2020).The Family that Prays Together, Stays Together: Toward a Process Model of Religious Value Transmission in Family Firms. Journal of Business Ethics.

Bhatnagar, N., Sharma, P., \& Ramachandran, K. (2020). Spirituality and Corporate Philantrophy in Indian Family Firms: An Exporatory Study. Journal of Business Ethics.

Binz Astrachan, C., Ferguson, K. E., Pieper, T. M., \& Astrachan, J. H. (2017). Family business goals, corporate citizenship behaviour and firm performance: disentangling the connections. International Journal of Management and Enterprise Development, 16(1-2), 34-56.

Blodgett, M. S., Dumas, C., \& Zanzi, A. (2011). Emerging trends in global ethics: A comparative study of US and international family business values. Journal of Business Ethics, 99(1), 29-38.

Campbell, L., Gulas, C. S., \& Gruca, T. S. (1999). Corporate giving behavior and decisionmaker social consciousness. Journal of Business Ethics, 19(4), 375-383.

Carradus, A., Zozimo, R. \& Discua Cruz, A. (2020). Exploring a Faith-Led Open Systems Perspective of Stewardship in Family Businesses. Journal of Business Ethics.

Cennamo, C., Berrone, P., Cruz, C., \& Gomez-Mejia, L. R. (2012). Socioemotional wealth and proactive stakeholder engagement: Why family-controlled firms care more about their stakeholders. Entrepreneurship Theory and Practice, 36(6), 1153-1173. 
Chan, K. Q., Tong, E. M. W., \& Tan, Y. L. (2014). Taking a leap of faith: Reminders of God lead to greater risk taking. Social Psychological and Personality Science, 5(8), 901909.

Chrisman, J. J., Chua, J. H., Pearson, A. W., \& Barnett, T. (2012). Family involvement, family influence, and family-centered non-economic goals in small firms. Entrepreneurship Theory and Practice, 36(2), 267-293.

Chua, J. H., Chrisman, J. J., \& Sharma, P. (1999). Defining the family business by behavior. Entrepreneurship theory and practice, 23(4), 19-39.

Combs, J. G., Shanine, K. K., Burrows, S., Allen, J. S., \& Pounds, T. W. (2019). What do we know about business families? Setting the stage for leveraging family science theories. Family Business Review.

Copeland, M. K. (2014). The emerging significance of values based leadership: A literature review. International journal of leadership studies, 8(2), 105.

Crossan, M., Mazutis, D., \& Seijts, G. (2013). In search of virtue: The role of virtues, values and character strengths in ethical decision making. Journal of Business Ethics, 113(4), 567-581.

Cruz, C., Larraza-Kintana, M., Garcés-Galdeano, L., \& Berrone, P. (2014). Are family firms really more socially responsible?. Entrepreneurship Theory and Practice, 38(6), 12951316.

Daspit, J. J., Holt, D. T., Chrisman, J. J., \& Long, R. G. (2016). Examining family firm succession from a social exchange perspective: A multiphase, multistakeholder review. Family Business Review, 29(1), 44-64.

Davis, J. H., Allen, M. R., \& Hayes, H. D. (2010). Is blood thicker than water? A study of stewardship perceptions in family business. Entrepreneurship Theory and Practice, 34(6), 1093-1116.

De Massis, A., Kotlar, J., Mazzola, P., Minola, T., \& Sciascia, S. (2018). Conflicting selves: Family owners' multiple goals and self-control agency problems in private firms. Entrepreneurship theory and practice, 42(3), 362-389.

Denison, D., Lief, C., \& Ward, J. L. (2004). Culture in family-owned enterprises: Recognizing and leveraging unique strengths. Family Business Review, 17(1), 61-70.

Dielemann, M., Koning, J. (2020). Articulating Values through Identity Work: Advancing Family Business Ethics Research. Journal of Business Ethics.

Discua Cruz, A. (2013). Christian Family Businesses: Opportunities for Future Research. Journal of Biblical Integration in Business, 16(2).

Distelberg, B., \& Sorenson, R. L. (2009). Updating systems concepts in family businesses A focus on values, resource flows, and adaptability. Family Business Review, 22(1), 6581.

Driscoll, C., McIsaac, E. M., \& Wiebe, E. (2019). The material nature of spirituality in the small business workplace: from transcendent ethical values to immanent ethical actions. Journal of Management, Spirituality \& Religion, 16(2), 155-177.

Fang, H., Van de Graaff Randolph, R., Chrisman, J. J., \& Barnett, T. (2013). Firm religiosity, bounded stakeholder salience, and stakeholder relationships in family firms. Journal of Management, Spirituality \& Religion, 10(3), 253-270.

Fathalla, R., Sidani, Y., Khalil, S. (2020). How Religion Shapes Family Business Ethical Behaviors: An Institutional Logics Perspective. Journal of Business Ethics

Ford, R. C., \& Richardson, W. D. (1994). Ethical decision making: A review of the empirical literature. Journal of business ethics, 13(3), 205-221.

Fritzsche, D., \& Oz, E. (2007). Personal values' influence on the ethical dimension of decision making. Journal of Business Ethics, 75(4), 335-343. 
García-Álvarez, E., \& López-Sintas, J. (2001). A taxonomy of founders based on values: The root of family business heterogeneity. Family Business Review, 14(3), 209-230.

Gümüsay, A. A., Smets, M., \& Morris, T. (2019). 'God at Work': Engaging Central and Incompatible Institutional Logics through Elastic Hybridity. Academy of Management Journal.

Halek, M., \& Eisenhauer, J. G. (2001). Demography of risk aversion. Journal of Risk and Insurance, 1-24.

Hammond, N. L., Pearson, A. W., \& Holt, D. T. (2016). The quagmire of legacy in family firms: Definition and implications of family and family firm legacy orientations. Entrepreneurship Theory and Practice, 40(6), 1209-1231.

Hernandez, M. (2012). Toward an understanding of the psychology of stewardship. Academy of Management Review, 37(2), 172-193. https://doi.org/10.5465/amr.2010.0363

Hilary, G., \& Hui, K. W. (2009). Does religion matter in corporate decision making in America? Journal of Financial Economics, 93(3), 455-473.

Hill, P. C., Pargament, K. I., Hood, R. W., McCullough, J. M. E., Swyers, J. P., Larson, D. B., \& Zinnbauer, B. J. (2000). Conceptualizing religion and spirituality: Points of commonality, points of departure. Journal for the theory of social behaviour, 30(1), $51-77$.

Kaye, K. (1996). When the family business is a sickness. Family Business Review, 9(4), 347368.

Kavas, M., Jarzabowski, P., Nigam, A. (2020). Islamic Family Businesses: The Constitutive Role of Religion in Business. Journal of Business Ethics

Kellermanns, F. W. (2013). Spirituality and religion in family firms. Journal of Management, Spirituality \& Religion, 10(2), 112-115.

Kidwell, R. E., Kellermanns, F. W., \& Eddleston, K. A. (2012). Harmony, justice, confusion, and conflict in family firms: Implications for ethical climate and the "Fredo effect". Journal of Business Ethics, 106(4), 503-517.

Kotlar, J., \& De Massis, A. (2013). Goal setting in family firms: Goal diversity, social interactions, and collective commitment to family-centered goals. Entrepreneurship Theory and Practice, 37(6), 1263-1288.

La Porta, R., Lopez-de-Silanes, F., \& Shleifer, A. (1999). Corporate ownership around the world. The journal of finance, 54(2), 471-517.

Lewer, J. J., \& Van den Berg, H. (2007). Religion and International Trade: Does the sharing of a religious culture facilitate the formation of trade networks?. American Journal of Economics and Sociology, 66(4), 765-794.

Loe, T. W., Ferrell, L., \& Mansfield, P. (2000). A review of empirical studies assessing ethical decision making in business. Journal of business ethics, 25(3), 185-204.

Madison, K., Holt, D. T., Kellermanns, F. W., \& Ranft, A. L. (2016). Viewing family firm behavior and governance through the lens of agency and stewardship theories. Family Business Review, 29(1), 65-93.

Marques, P., Presas, P., \& Simon, A. (2014). The heterogeneity of family firms in CSR engagement: The role of values. Family Business Review, 27(3), 206-227.

Maung, M., Miller, D., Tang, Z., \& Xu, X. (2020). Value-Enhancing Social Responsibility: Market Reaction to Donations by Family vs. Non-Family Firms with Religious CEOs. Journal of Business Ethics.

Naldi, L., Cennamo, C., Corbetta, G., \& Gomez-Mejia, L. (2013). Preserving socioemotional wealth in family firms: Asset or liability? The moderating role of business context. Entrepreneurship Theory and Practice, 37(6), 1341-1360. 
Neubaum, D. O., Thomas, C. H., Dibrell, C., \& Craig, J. B. (2017). Stewardship Climate Scale: An Assessment of Reliability and Validity. Family Business Review, 30(1), $37-$ 60. https://doi.org/10.1177/0894486516673701

Olson, P. D., Zuiker, V. S., Danes, S. M., Stafford, K., Heck, R. K., \& Duncan, K. A. (2003). The impact of the family and the business on family business sustainability. Journal of business venturing, 18(5), 639-666.

Paterson, T. A., Specht, D., \& Duchon, D. (2013). Exploring costs and consequences of religious expression in family businesses. Journal of Management, Spirituality \& Religion, 10(2), 138-158.

Patten, D. M. (2008). Does the market value corporate philanthropy? Evidence from the response to the 2004 tsunami relief effort. Journal of Business Ethics, 81(3), 599-607.

Pieper, T., Williams Jr., R.I., Manley, S.C. \& Matthews, L.M. (2020). What Time May Tell: An Exploratory Study of the Relationship Between Religiosity, Temporal Orientation and Goals in Family Business. Journal of Business Ethics.

Pirson, M., Martin, K., \& Parmar, B. (2017). Formation of stakeholder trust in business and the role of personal values. Journal of Business Ethics, 145(1), 1-20.

Ravasi, D. and Lojacono, G. (2005). Managing design and designers for strategic renewal. Long Range Planning, 38(1), 51-77.

Soleimanof, S., Rutherford, M. W., \& Webb, J. W. (2018). The intersection of family firms and institutional contexts: A review and agenda for future research. Family Business Review, 31(1), 32-53.

Sorenson, R. L. (2013). How moral and social values become embedded in family firms. Journal of Management, Spirituality \& Religion, 10(2), 116-137.

Stead, W. E., Worrell, D. L., \& Stead, J. G. (1990). An integrative model for understanding and managing ethical behavior in business organizations. Journal of Business Ethics, 9(3), 233-242.

Tabor, W., Madison, K., Marler, L.E., Kellermanns, F.W. (2020). The Effects of Spiritual Leadership in Family Firms: A Conservation of Resources Perspective. Journal of Business Ethics.

Top, J. (2019). Spirituality: The Core of Leadership. Marine Corps Gazette, 103(8), 66-69.

Treviño, L. K., Weaver, G. R., \& Reynolds, S. J. (2006). Behavioral ethics in organizations: A review. Journal of Management, 32(6), 951-990.

Vallejo, M. C. (2009). The effects of commitment of non-family employees of family firms from the perspective of stewardship theory. Journal of Business Ethics, 87(3), 379390.

Vazquez, P. (2016). Family business ethics: At the crossroads of business ethics and family business. Journal of Business Ethics, 1-19.

Wang, G., \& Hackett, R. D. (2016). Conceptualization and measurement of virtuous leadership: Doing well by doing good. Journal of Business Ethics, 137(2), 321-345.

Wicks, A. (2014). Stakeholder theory and spirituality. Journal of Management, Spirituality \& Religion, 11(4), 294-306.

Yan, J., \& Sorenson, R. L. (2004). The influence of Confucian ideology on conflict in Chinese family business. International Journal of Cross Cultural Management, 4(1), 5-17.

Yusof, M., Mohd Nor, L., \& Edward Hoopes, J. (2014). Virtuous CSR: an Islamic family business in Malaysia. Journal of Family Business Management, 4(2), 133-148. 